Lowry OH, Rosebrough NS, Paurr AL, Randall RJ (1951) Protein measurement with FolinPhenol reagent. J Biol Chem 193:265 - 75

Parmar MT, Moore RP (1968) Carbowax 6000, mannitol and sodium chloride for simulating drought conditions in germination studies of corn (Zea mays L.) of strong and weak vigour. Agron J 60: $192-95$

Sandhu RS, Jaswal SV, Sangha AS (1975) The performance of variety M-13 in comparison with some approved varieties of groundnut (Arachis hypogaea L.) in Punjab. J Res Punjab Agric Univ 11:350 - 54

Todd GW, Webster DL (1965) Effect of repeated drought period on photosynthesis and survival of cereal seedlings. Agron J 57:399 - 404

Weatherley PE (1950) Studies in the water relations of the cotton plant. I. The field measurement of water deficit in leaves. New Phytol 49:81 - 97

\title{
Erratum
}

\section{Calibration of Thermocouple Hygrometers *}

\author{
M. J. Savage, A. Cass, and J. M. de Jager
}

Department of Soil Science and Agrometeorology, University of Natal, PO Box 375, Pietermaritzburg, Natal, South Africa 3200

Irrig Sci (1981) 2:113-125

Page 119, Equation (8) add $\frac{K_{T}}{K_{25}}$ to right hand term of the equation

to read

$$
\text { or } \frac{\psi_{w}}{\psi_{25}}=\frac{K_{T}}{K_{25}},(\mathrm{a}+\mathrm{bTc}) .
$$

Responsible for the text: The Editor-in-Chief

For advertisements: E. Lückermann, Kurfürstendamm 237, D-1000 Berlin 15, Springer-Verlag, Berlin · Heidelberg New York

Printed in Germany by K. Triltsch, Würzburg

Copyright $(1)$ by Springer-Verlag Berlin $\cdot$ Heidelberg 1981 